\title{
Profilaktyka społeczna jako działalność intensyfikująca odporność psychiczną
}

\author{
Social prevention as an activity to intensify mental resilience
}

\begin{abstract}
Streszczenie
Działania profilaktyczne zapobiegają pojawiającym się problemom społecznym, przy wykorzystaniu różnych metod i narzędzi do pracy. Niniejszy artykuł przybliży pomysł na prowadzenie profilaktyki społecznej, przy pomocy paintballu i survivalu, jako narzędzi do pracy terapeutycznej. Profilaktyka społeczna oparta na elementach przetrwania ma charakter zajęć rekreacyjnych, które przygotowują uczestników do podejmowania działań w trudnych warunkach i do poszukiwania dróg radzenia sobie z własnymi słabościami. W badaniach nad wzmocnieniem odporności psychicznej przyjmuję koncepcję teorii ugruntowanej, opartej na przeprowadzonych wywiadach i obserwacji uczestniczącej. Profilaktyka społeczna z elementami paintballu i sztuki przetrwania posiada w sobie takie cechy, które wzmacniają odporność psychiczną, uczą pewności siebie i wytrwałości. Profilaktyka ruchowa posługuje się ludzkim potencjałem, energią i werwą, po to, aby w jak najlepszy sposób wykorzystać te elementy w praktycznym doświadczaniu życia. Aktywność fizyczna wywołuje pozytywne zmiany w funkcjonowaniu człowieka i uczy sposobów reagowania na trudne sytuacje. Celem artykułu jest dostarczenie wiedzy badawczej, dotyczącej natężenia odporności psychicznej, od graczy paintballowych, którzy są organizatorami działań profilaktycznych. Opracowane materiały posłużą
\end{abstract}

1 Karol Łukowski, Wydział Nauk o Wychowaniu, Uniwersytet Łódzki, Polska, e-mail: karol. lukowski123@gmail.com, ORCID ID: https://orcid.org/0000-0003-3057-792X. 
do budowania alternatywnej wizji spędzania wolnego czasu dla dzieci i młodzieży oraz ich rodziców.

\title{
Słowa kluczowe:
}

profilaktyka, społeczna, działalność, intensyfikacja, odporność, psychiczna

\begin{abstract}
Preventive activities prevent emerging social problems, using various methods and tools for work. This article will introduce the idea of conducting social prevention using paintball and survival, as tools for therapeutic work. Social prevention based on the elements of survival has the nature of recreational activities that prepare participants to take action in difficult conditions and to look for ways to deal with their own weaknesses. In research on strengthening mental resilience, I adopt the concept of grounded theory, based on interviews and participant observation. Social prophylaxis with elements of paintball and the art of survival has features that strengthen mental resilience, teach self-confidence and persistence. Movement prophylaxis uses human potential, energy, and verve to make the best use of these elements in the practical experience of life. Physical activity causes positive changes in human functioning and teaches how to react to difficult situations. The aim of the article is to provide research knowledge on the strength of mental resilience from paintball players who organize preventive measures. The developed materials will be used to build an alternative vision of spending free time for children, adolescents, and their parents.
\end{abstract}

\section{Keywords:}

prevention, social, activity, intensification, resilience, mental

\section{WSTĘP}

Szeroko rozumiana profilaktyka społeczna koncentruje się na działaniach ograniczających wszelkiego rodzaju zagrożenia i wykluczenia społeczne oraz odnosi się do stosowania metod korekcyjnych wobec nieprawidłowości w sposobie funkcjonowania i zaburzeń zachowania. Profilaktykę w ujęciu rozwojowym można odnieść do pracy nad sobą, nad swoimi ograniczeniami, przekonaniami, emocjami i cechami charakteru oraz rozwojem własnych zainteresowań. Profilaktyka to interdyscyplinarna dziedzina naukowo-praktyczna, która porusza kwestie, w jaki sposób zagospodarować wolny czas, gdzie szukać pomocy i potrzebnych informacji. Profilaktyka w ujęciu praktycznym jest działaniem dodatnim, które przynosi 
wiele korzyści dla funkcjonowania człowieka w społeczeństwie i ma na celu zapobieganie oraz reagowanie na szkodliwe i niepożądane zjawiska, problemy i sytuacje. Profilaktyka społeczna edukuje w zakresie, jak myśleć i postępować, aby nie być narażonym na niekorzystne czynniki środowiskowe, by nie znaleźć się w beznadziejnej dla siebie sytuacji, natomiast sztuka przetrwania kształtuje w człowieku umiejętności, które pozwalają na przetrwanie w trudnych warunkach środowiskowych. Zatem elementy sztuki przetrwania wzmacniają swoimi właściwościami działania profilaktyczne, dostarczają cennej wiedzy i uczą niezbędnych umiejętności przetrwania w trudnych, uciążliwych, niejasnych i niebezpiecznych warunkach. Elementy paintballowe, wykorzystywane jako narzędzia pracy profilaktycznej, rozwijają w ludziach wytrwałość, wytrzymałość, odporność na stres, uodparniają na negatywne skutki życia codziennego i uczą przyzwyczajania się do własnych lęków. Profilaktyka społeczna nad intensyfikacją odporności psychicznej, związana jest z pracą nad wzmacnianiem komponentów, na które składają się nasze zdolności, zachowania, myśli, sposób bycia i działania, a człowiek może się ich uczyć i rozwijać w sobie. Profilaktyka to proces, który wspiera ludzi w prawidłowym rozwoju i zdrowym życiu, dostarczając im pomocy w radzeniu sobie ze złożonymi, stresującymi warunkami życia, a w efekcie umożliwia im satysfakcjonujące i bogate życie (Gaś, 2004, s. 166).

\section{ZAŁOŻENIE DZIAŁAŃ PROFILAKTYCZNYCH INTENSYFIKUJĄCYCH ODPORNOŚĆ PSYCHICZNĄ}

Profilaktyka społeczna ma za zadanie zmniejszanie szkód społecznych, eliminowanie występujących nieprawidłowości, wypracowanie jakościowej strategii działań, po to, aby odnieść zamierzony rezultat. W poszukiwaniu cech rozwijających działalność profilaktyczną, które wzmacniają człowieka w osiąganiu założonych celów i wspierają pracę nad jakością inicjowanych technik profilaktyczno-terapeutycznych, można odnieść się do przyswajania wiedzy poprzez praktykowanie wytrwałości, która wymaga pracy nad samym sobą, wyższego poziomu cierpliwości i bieżącego realizowania postawionych sobie zadań. Profilaktyka społeczna nastawiona jest na działania ograniczające zagrożenia, które stwarzają ryzyko dla ludzi oraz prowadzą do pewnych negatywnych skutków, takich jak: utrata zdrowia, dysfunkcje, nieprawidłowości w funkcjonowaniu, uzależnienia, zaburzenia zachowania i wykluczenia społeczne. Profilaktyka ma na celu eliminowanie zaburzonych schematów zachowań, uciążliwych zależności i szkodliwych dla człowieka przyzwyczajeń, którymi posługuje się na co dzień. Działania profilaktyczne mają 
za zadanie stać się realną odpowiedzią na rzeczywiste zapobieganie i ograniczanie występujących zagrożeń społecznych. Zatem bardzo ważny jest praktyczny rozwój metod działań i wiedzy na temat profilaktyki społecznej, poprzez podejmowanie przemyślanych działań edukacyjnych, rozwojowych i terapeutycznych w obszarach związanych z dysfunkcjami psychospołecznymi, zaburzeniami zachowania oraz różnego rodzaju uzależnieniami. Profilaktyka społeczna może spełniać swoje zadanie w zakresie poszukiwania metod na ograniczanie presji życia codziennego, poprzez wypracowanie sposobów pracy terapeutycznej na radzenie sobie z trudnymi sytuacjami i problemami życiowymi, za pomocą ewaluacji, superwizji i sprawdzania skuteczności efektów końcowych. Praktyka profilaktyczna, podobnie jak sztuka przetrwania, uczy, w jaki sposób poradzić sobie w sytuacji kryzysowej, poprzez obmyślanie i wdrażanie strategii i skutecznych sposobów działań. Profilaktyka społeczna jest pewnym sposobem myślenia, który ma na celu pokonywanie, omijanie i eliminowanie przeszkód, za pomocą wzmacniania zdrowego stylu życia i budowania zdrowych relacji społecznych. Pokonywanie kolejnych przeszkód popycha do dalszego działania, natomiast zmierzenie się z trudnościami wydobywa z ludzi wszystko to, co jest w nich najlepsze. Szybkie działanie pokazuje wyjątkowe zdolności, subtelność w myśleniu i rozwagę w czynach (Baltasar, 2010, s. 48).

\section{CHARAKTERYSTYKA KONCEPCJI BADAWCZEJ NAD INTENSYFIKACJA ODPORNOŚCI PSYCHICZNEJ}

Badania mają na celu przyjrzenie się Intensyfikacji odporności psychicznej u ludzi grajq̨cych w paintball, którzy sq realizatorami działań profilaktycznych. W badaniach pozyskana została praktyczna wiedza bezpośrednio od uczestników gier paintballowych, którzy prowadzą działania profilaktyczne, co świadczy o ich profesjonalnym przygotowaniu do wykonywanych zadań na rzecz innych ludzi. Do wdrażania i realizowania przemyślanych zadań profilaktycznych, przy użyciu sztuki survivalu i paintballu, potrzebna jest kadra, która wie, co robi i ma szczegółowo opracowany plan działań. Pierwszą organizacją, która opracowała zastosowanie metody surviwalu i paintballu jako narzędzi do pracy terapeutyczno-profilaktycznej, była Fundacja Bądź Zaradny.

Badanie zostało przeprowadzone na siedmiu osobach, wszyscy to mężczyźni, wywiady były prowadzone dwukrotnie, w sumie zanotowano 14 wywiadów. Po pojęciem intensyfikacji odporności psychicznej, na podstawie przeprowadzonych wywiadów, dochodzi się do wniosków, że wzmocnienia odnoszą się do budowania zdolności związanych z wewnętrznym wyposażeniem człowieka i predyspozy- 
cjami do skutecznego radzenia sobie z wyzwaniami codziennego życia. Pomysł na wzmocnienie pracy profilaktycznej elementami suvivalu i paintballu został oparty na praktycznym spojrzeniu i zrealizowanych projektach szkolnych, edukacyjnych, terapeutycznych i społecznych. Założeniem aranżowanych metod pracy profilaktycznej jest oswajanie młodych ludzi, by przetrwali w trudnych i niedogodnych warunkach oraz sami potrafili usunąć lub ominąć postawiane im przeszkody. Oswajanie uczestników z utrudnieniami uczy ich poszukiwania drogi do wyjścia z niedogodnych sytuacji, zaradności, wytrwałości i umiejętności społecznych, poprzez co uczestnicy gier paintballowych i survivalu, podejmują aktywności, które doprowadzają ich do rozwiązania danego problemu. Sama adaptacja do niekorzystnych warunków i podjęta interwencja wykształca reakcję na niedogodną sytuację w postaci impulsu do szybkiego reagowania, myślenia i samodzielnego podjęcia szybkiej decyzji. Praca terapeutyczna oparta na elementach sztuki przetrwania ma zastosowanie jako funkcjonalna metoda do wspierania sfer rozwojowych i wzmacniania odporności psychicznej.

\section{OPIS METODOLOGII BADAŃ}

W badaniach nad Intensyfikacjq odporności psychicznej u ludzi grajq̨cych w paintball, którzy sq realizatorami działań profilaktycznych została przyjęta klasyczna koncepcja opracowana przez Barney’a G. Glasera i Anselma L. Straussa, umocowana w teorii socjologicznej, zwana symbolicznym interakcjonizmem, według której decydującym sposobem formowania się wzajemnie ze sobą powiązanych elementów społeczeństwa jest nieustanie trwające przeistaczanie teorii i stopniowy proces zmian znaczeń i pojęć.

Teoria ugruntowana to jakościowa metoda badawcza, która poprzez systematyczne zbieranie i analizowanie danych prowadzi do wygenerowania teorii. W badaniach szczególną uwagę zwróciłem na opis doświadczeń uczestników. Teoria ugruntowana ujmuje badane zjawiska w kontekście społecznym, podkreślając ich procesualność oraz interaktywność (Glaser i Strauss, 2009, s. 34), opiera się na założeniu, że rzeczywistość społeczną najlepiej rozumieją zaangażowani w nią aktorzy i to ich perspektywa powinna być głównie rekonstruowana. Teoria musi być łatwo zrozumiała dla socjologów o dowolnych zapatrywaniach, dla studentów i niespecjalistów w tej dziedzinie. Teoria, która potrafi spełnić te wymagania, powinna być dopasowana do sytuacji będącej przedmiotem badania i pracować, gdy zostaje użyta (Glaser i Strauss, 2009, s. 9). Teoria ugruntowana stwarza warunki do opracowania koncepcji badawczej i wyjaśnia podstawowe myśli, 
które są przedmiotem problemu do rozważania. Wspólną podstawą praktycznego zastosowania teorii ugruntowanej są cztery silnie powiązane ze sobą właściwości. Pierwszą właściwością jest dopasowanie teorii do obszaru rzeczowego, w którym będzie używana. Druga prawidłowość odnosi się do rozumienia teorii przez laików. Trzecie założenie dotyczy ogólności teorii, ażeby dało się ją zastosować w wielu codziennych sytuacjach. Czwartym argumentem jest umożliwienie użytkownikowi częściowej kontroli nad zmieniającymi się w czasie strukturami i procesami codziennego życia (Glaser i Strauss, 2009, s. 185).

Metodą zbierania danych, był wywiad narracyjny, który pozwolił na uzyskanie analitycznego wglądu w subiektywne struktury sensu i działania jednostek. Metoda ta wykorzystywana jest w badaniach jakościowych, gdzie przyjmuje się założenie, że świat społeczny jest światem konstruowanym przez działania, wzajemne oddziaływania ludzi, a konstrukcja wywiadu odznacza się sensem i znaczeniem. Ludzie, obserwując określone sytuacje czy zachowania innych, interpretują je i korzystają, nie zawsze świadomie, z posiadanej wiedzy (Urbaniak-Zając i Kos, 2019, s. 23). Do uzupełnienia danych zastosowałem obserwację uczestniczącą, która miała miejsce wtedy, gdy jako badacz byłem uczestnikiem społeczności badanych osób, przez co miałem lepszy dostęp do danych. Obserwacja przeprowadzona w taki sposób pomogła dokładniej rozumieć działania ludzi, wczuć się w ich sytuację i uczyć się przez doświadczenie.

Grupą badaną są osoby zajmujące się działaniami i realizacją projektów z zakresu profilaktyki społecznej i promocji zdrowia. Uczestnicy badań to ludzie, który wolny czas spędzają na grze w paintball, a ich pasją jest podejmowanie inicjatyw na płaszczyźnie sztuki przetrwania i paintballu, które świadczą na rzecz dzieci, młodzieży i ludzi dorosłych. Grupą badawczą jest siedmiu zawodników, a zarazem działaczy społecznych pochodzących z Anglii i Polski. Najczęściej zadawane pytania badawcze odnosiły się do tego, co robią badani, aby wzmacniać własną odporność psychiczną, co czyni ich silniejszymi, co robią, by poczuć się lepiej, oraz w jaki sposób dbają o własne zdrowie psychiczne. Wywiad przeprowadziłem w trakcie trwania gier paintballowych na Poligonie Zona Paintball Łódź, rozmawiałem z uczestnikami badań osobiście oraz za pośrednictwem internetu.

\section{PRZEBIEG BADAŃ NAD INTENSYFIKACJĄ ODPORNOŚCI PSYCHICZNEJ}

Intencją badacza jest prezentacja opisu przebiegu procesu badawczego i podejmowanych działań z perspektywy doświadczeń realizatorów programów profilaktycznych, którzy są zawodnikami grającymi w paintball i organizują inicjatywy 
z zakresu sztuki przetrwania. Badaniu zostali podani zawodnicy, którzy zajmują się działalnością profilaktyczną na rzecz dzieci młodzieży i ich rodzin, z drużyn takich jak: Going Postal, ADHD Paintball, Horse Team i Paint no Pain. Odpowiedzi na pytania badawcze były bardzo zróżnicowane.

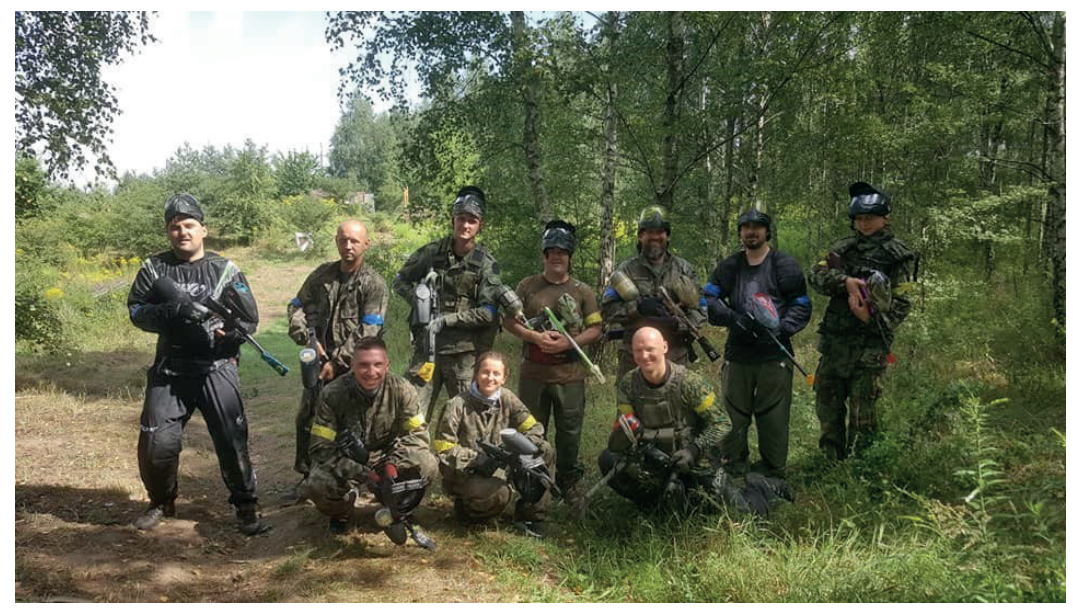

Zdjęcie 1. Uczestnicy gry paintballowej na Zona Łódź Źródło: Materiał Zona Łódź.

Jeden z przykładów wzmacniania odporności psychicznej, który został zaprezentowany przez badanego, nawiązuje do samej gry w paintball, która dostarcza wiele wskazówek na temat stawania się bardziej przenikliwym, natomiast intensywność rozgrywek i przebywanie w ciężkich warunkach wzmacnia jego odporność, a samo uczestnictwo w grze i przebywanie w trudnych warunkach sprawia mu satysfakcję. Przenoszenie nabytych umiejętności u badanego na grunt codzienny ułatwia mu przeżywanie trudnych stanów i bliższe przyjrzenie się własnym emocjom w sytuacjach ekstremalnych. Emocje, które mu towarzyszą podczas gry w paintball, sprawiają, że potrafi bliżej je poznać, pobyć z nimi i przyjrzeć się im, a przez przechodzenie tych wszystkich nieudogodnień lepiej adaptuje się do otoczenia, co ułatwia mu sprawniejsze działanie. W tym przypadku gra w paintball zapobiega różnym sytuacjom stresującym w jego życiu, które wcześniej jest w stanie rozpoznać i podjąć decyzję o ominięciu pojawiającej się przeszkody psychologicznej lub przystąpić do rozwiązania zaistniałych problemów i trudnych myśli, jakie go spotykają.

Kolejny uczestnik udziela odpowiedzi na pytanie, co robi, aby wzmocnić własną odporność psychiczną. Odniósł to do własnej spontanicznej pomysłowości, inwencji twórczej danej chwili, stara się jak najlepiej zagrać i zastosować to, czego 
wcześniej się nauczył. W sytuacjach kryzysu na polu paintballowym próbuje przetrwać grę, a jeśli się mu to nie uda, to skupia się na tym, co sprawiło mu najwięcej trudności, i poprawia te elementy gry w następnej rozgrywce. Gracz ten zwraca szczególną uwagę na szybkość zmian podczas gry w paintball, że własne ułożenie planu gry, w postaci scenariusza danej rozgrywki, nie jest możliwe, ponieważ paintball jest grą dynamiczną i szybko się zmieniają ustawienia na polu gry, ale pomimo tego próbuje realizować indywidualną i drużynową strategię. W tym przypadku można dostrzec układanie własnego planu strategii działania, realizacji, wprowadzania zmian i wyciągania wniosków z gry.

Inny uczestnik podkreślił, że będzie grać jak najczęściej w paintball, o ile będzie mu na to pozwalała sytuacja finansowa i zdrowie; powiedział mi to, chociaż nie zadałem mu pytania, w postaci: Jak często grasz w paintball? Natomiast zapytałem z żartem: Co robisz dalej, jak już jesteś zadowolony? Po zastanowieniu się przez gracza usłyszałem odpowiedź, że nic więcej już nie musi robić. Głównym celem w podejściu do gry u badanego jest zdecydowanie satysfakcja z gry i aktywne spędzanie wolnego czasu. Stojący obok uczestnik badania stwierdził podobnie, że stara się jak najlepiej i z pożytkiem dla siebie wykorzystać czas na polu do gry.

Następny zawodnik rozgrywek był bardzo zainteresowany tematem edukacji zdrowotnej, stwierdził, że aktywność ruchowa czynni go silniejszym psychicznie i zdrowszym, rozwija zarówno ciało, jak i umysł, pozwala na wykorzystanie umiejętności z pola gry w życiu codziennym, a zdolności psychologiczne same przychodzą wraz z regularną grą. Zachęcał ludzi, by grali jak najczęściej w paintball, by dbali o własne zdrowie i myślenie. Uważa, że gra w paintball jest aktywnością wspierającą zdrowy styl życia, że wzmacnia ciało i rozwija sztukę myślenia. Sztuka przetrwania jest dla badanego dobrym pomysłem na spędzanie wolnego czasu, a na podstawie własnego doświadczenia wyprowadził następujące stwierdzenia, że gra w paintball i ćwiczenia survivalowe budzą umysł do myślenia i uruchamiają jasność w myśleniu, pozwalają na wykorzystanie umiejętności z pola gry w codziennym życiu, a sprawność fizyczna i myślenie strategiczne przychodzą wraz z regularną grą.

Wypowiedzi trzech uczestników grających w paintball były zbieżne, ponieważ stwierdzili, że ich udział w survivalu i grach paintballowych, poprzez doświadczanie przeszkód i trudności, umożliwił im wnikliwe zapoznanie się z własnymi cechami charakteru, przez co mogą lepiej poznać swoje ograniczenia, słabości i zalety, co uczy rozwijania ich zasobów, którymi dysponują.

Angielski badany, grający w paintball dla przyjemności, oznajmił, że czynności wzmacniające odporność psychiczną nadają jego nastawieniu do życia korzystnych zmian, które mają wpływ na jego stan psychiczny i fizyczny, poprzez grę w pa- 
intball odczuwa uczucie zadowolenia. W tym przypadku paintball to pasja i ma pozytywny wpływ na kierunek myślenia, bez względu na to, jaki badany ma humor, dzień i jak się czuje, jeżeli czuje się słabiej, to paintball poprawia mu nastrój. Sama myśl o grze w paintball działa na niego samoczynnie, nakręcając go, wyzwalając przychylne myśli dla gracza, co powoduje u niego dobre samopoczucie.

Na pytanie na temat wzmacniania jakości życia stojący obok opiniodawca odparł, że życie to ciężki proces z wieloma wzlotami i upadkami. Chodzi o to, aby wziąć swoje życie takie, jakie jest. We wszystkim, co w życiu robisz, ważne jest to, w jaki sposób interpretujesz dane wydarzenia, rzeczy i sytuacje, które cię spotykają. Badany zaopiniował, że można dla siebie samego dużo zrobić, jak się tylko tego chce i wie się, jak to zrobić, a stany przygnębienia w dużej mierze wywołują czynniki zewnętrzne i uzewnętrzniają nasze ułomności. Uważa, że nie mamy na wszystko wpływu, ale powinniśmy wzmacniać nasz umysł na różne sposoby. Czasami może to być trudne, ale zawsze warto spróbować. Chcąc się dowiedzieć, co robi badany, aby się wzmocnić, i jak sobie radzi ze szkodliwymi czynnikami środowiskowymi, usłyszałem odpowiedź, iż jaki styl życia prowadzimy, tak się czujemy. To nasze postępowanie, dbanie o umysł, myśli i kondycje ciała, jest tym, co czyni człowieka silniejszym, więc jeśli możemy w jakikolwiek sposób zacząć dbać i wzmacniać swoją psychikę i ciało, to zacznijmy to robić, pamiętajmy o tym, by robić to codziennie i nieustannie. Natomiast paintball i elementy sztuki przetrwania są tylko kilkoma z wielu sposobów na wzmacnianie siebie.

Spotkałem się też z niepowszechną opinią na temat odporności psychicznej. Badany uznał, to pojęcie za wymyślone, ponieważ wszystko to, co mówi o nas, jest w naszej głowie, to, jak pojmujemy ograniczenie, i to, jak pokonujemy te ograniczenia. Pokonywanie swoich słabości badany obserwował u ludzi podczas desantu spadochronowego, gdzie pierwszy krok dla skaczących stanowi największe i decydujące wyzwanie. Przełamywanie się jest związane z przeżyciem przez nas trudnych dla siebie sytuacji i decyzji, które dotyczą samego momentu podjęcia czynności lub ich zaniechania, by mieć odwagę i ośmielić się zdecydować się na wykonanie tego kroku, który jest przeważającym czynnikiem spowodowania zmiany w swojej głowie. Badany realizator programów profilaktycznych, kończąc wypowiedź, podkreślił, że w zabawach survivalowych uczestniczą różni ludzie, a samo usprawnianie ćwiczeń ruchowych wzmacnia nasz organizm i poprawia sprawność naszego myślenia. Ćwicząc cokolwiek, musimy myśleć o tym, co robimy. 


\section{CHARAKTERYSTYKA DZIAŁAŃ NAD INTENSYFIKACJĄ ODPORNOŚCI PSYCHICZNEJ}

Dzięki obserwacji uczestniczącej można zauważyć zaangażowanie badanych w grę w paintball, jak działają i obmyślają strategię gry. Gra w paintball jest dynamiczna, gdzie szybko zmieniają się pozycje grających, których ważnymi cechami: są ostrożność, przezorność, spryt i uważność, a celem jest walka o zwycięstwo. Wzmacnianie profilaktyki społecznej, za pomocą przemyślanych działań, jako sztuki przetrwania uczy praktykowania ostrożności, dostrzegania przeciwności losu i uczenia się samodzielności do podejmowania wyjścia z trudnych dla siebie sytuacji.

Jeden z uczestników badania podczas wywiadu zdefiniował grę w paintball następującymi słowami, że grający w trakcie gry w paintball nie może stać w miejscu, bardzo często zmienia swoje pozycje strzeleckie, od zasłony do zasłony, i jest to gra, gdzie trzeba ciągle kombinować na polu, szukając dla siebie jak najlepszego wyjścia, po to aby wygrać walkę. Paintball to walka z przeciwnikiem, to konfrontowanie się $\mathrm{w}$ walce $\mathrm{z}$ innymi i szybkie reagowanie na zaistniałą sytuację. Bardzo widoczną rywalizację między graczami można zaobserwować w grze w paintball sportowy, gdzie gracze koncentrują się na rankingu, aby zajść jak najdalej w rozgrywkach.

Podczas przeprowadzonego wywiadu i obserwacji gier paintballowych można dojść do wniosku, że rywalizacja opiera się głównie na grze zespołowej. Paintball ma też własny repertuar gier, takich jak gra w wiatrak lub gra w vipa. Gra w wiatrak to gra na dominacje, a o wygranej decyduje dominacja na polu gry, którą liczy się poprzez mierzenie czasu gry. Gra polega na oznaczeniu graczy drużyn kolorami takimi, jakimi jest oznaczony wiatrak. Wiatrak ustawiony jest na środku pola do gry, czyli w miejscu, które jest najbardziej ostrzeliwane. Czas dla danej drużyny mierzy się dopiero wtedy, kiedy to zawodnik tej drużyny przestawi wiatrak na kolor swojej drużyny. Gra w wiatrak polega na jak najdłuższym utrzymywaniu przewagi przez daną drużynę na polu, gdzie cały czas trwa konfrontacja. Natomiast w grze w vipa jedna drużyna chroni vipa, a druga drużyna wchodzi w rolę terrorystów atakujących vipa. Celem terrorystów jest jego zlikwidowanie.

\section{AKTUALNY STAN BADAŃ NAD ODPORNOŚCIĄ PSYCHICZNĄ}

Dzisiejsza sytuacja na świecie jest powodem poważnych szkód społecznych, zdrowotnych, ekonomicznych i rozwojowych, co działa negatywnie na człowieka i zaburza naszą odporność psychiczną. Zatem pojawienie się nowych 


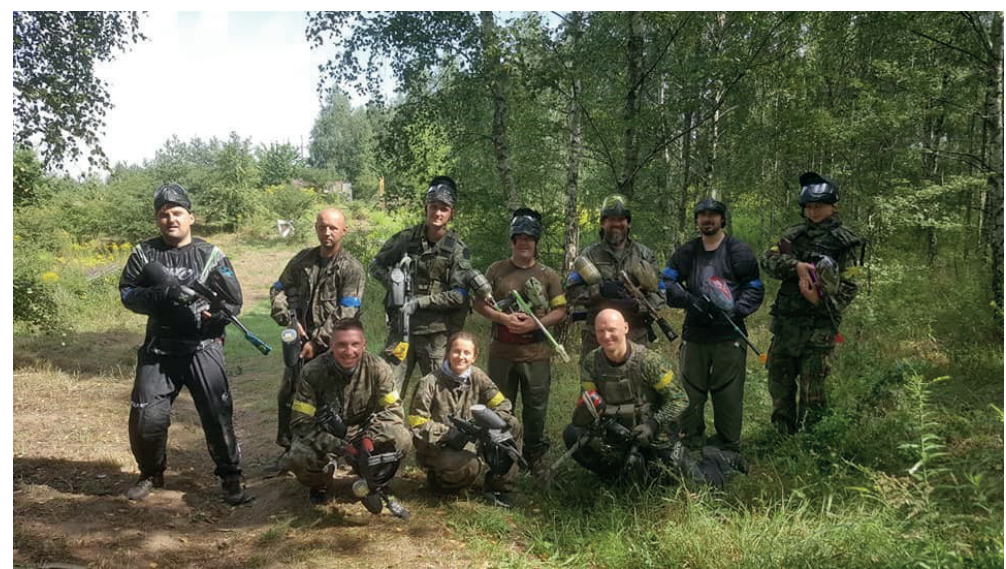

Zdjęcie 2. Gra w paintball

Źrodło: Materiał Fundacja Bądź Zaradny.

badań naukowych nad wzmacnianiem odporności psychicznej jest jak najbardziej uzasadnione.

Naukowcy David Fletcher i Mustafa Sarkar przeprowadzili badanie, które miało na celu wyjaśnienie związku między odpornością psychiczną a optymalnymi wynikami sportowymi. Celem badania była umiejętność radzenia sobie ze stresem,

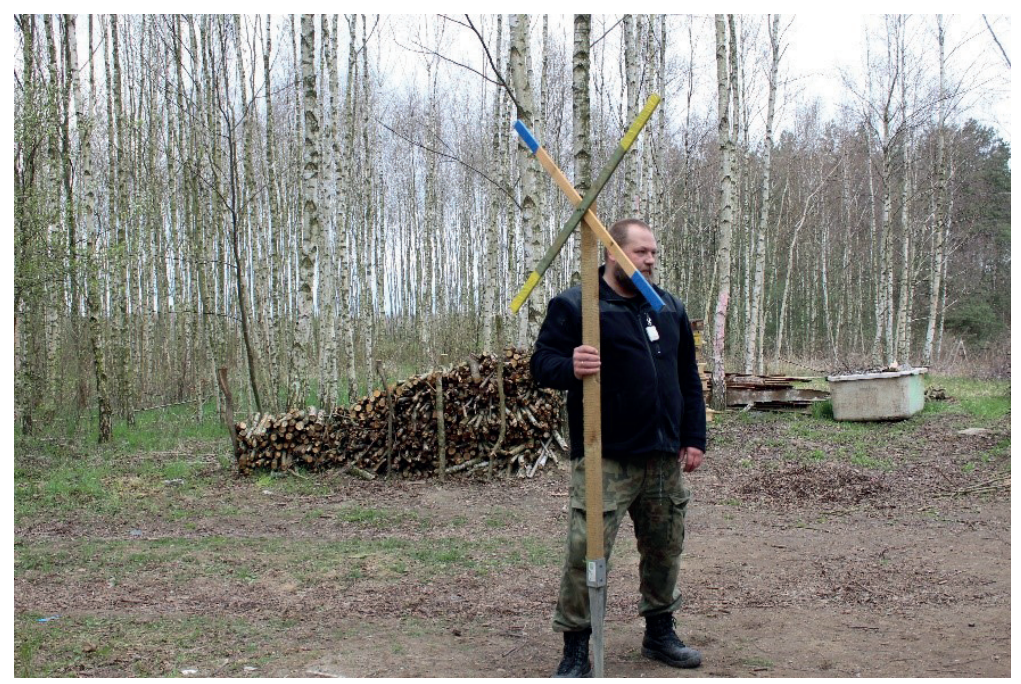

Zdjęcie 3. Instruktor paintballu tłumaczy grę w wiatrak Źródło: Materiał Fundacja Bądź Zaradny. 
który jest warunkiem wstępnym do doskonałości sportowej w konstruowaniu odporności psychicznej i nie był jeszcze systematycznie badany u sportowców. Metodą badawczą były wywiady z 12 mistrzami olimpijskimi, w tym ośmioma mężczyznami i czterema kobietami, reprezentującymi różne dyscypliny sportu. Zbierano informacje na temat doświadczeń sportowców odnoszących się do wytrzymałości i przeżywanej presji, która często towarzyszy sportowcom podczas kariery. Dane zbierano i analizowano za pośrednictwem zastosowania podejścia opartego na teorii ugruntowanej, wywiad analizowano przy użyciu kodowania otwartego, osiowego i wybiórczego. Rygor metodologiczny został ustalony poprzez włączenie różnych strategii weryfikacji do procesu badawczego. Teoria ugruntowana wynikała z oceny podstawowych kryteriów stosowanych w badaniach jakościowych, czyli dopasowania, trafności badanego problemu i możliwości jego modyfikacji. Wyniki badawcze wykazały, że czynniki psychologiczne wpływające na człowieka odnoszą się do pozytywnej osobowości, motywacji, pewności siebie, skupienia, sposobu postrzegania samego siebie i umiejętności korzystania ze wsparcia społecznego. Stwierdzono, że czynniki psychologiczne chronią sportowców przed negatywnym wpływem stresorów, wpływają na ich ocenę danego wyzwania, przed którym stoją. Dowiedziono, że proces ten wpływał pozytywnie na reakcje sportowców, ułatwiając im drogę do osiągania optymalnych wyników sportowych. Powstająca teoria badawcza zapewnia psychologom sportu, trenerom i krajowym organizacjom sportowym zrozumienie roli odporności w życiu sportowców i osiąganiu optymalnych wyników sportowych. Zaobserwowany został związek, pomiędzy odpornością a wynikami sportowymi. Zatem kształtowane w ludziach czynniki psychospołeczne chronią najlepszych sportowców przed stresem, natomiast ocena wyzwania i metapoznanie są ważnymi mechanizmami związanymi z odpornością, które ułatwiają i poprzedzają osiąganie optymalnych wyników sportowych (Fletcher i Sarkar, 2012, s. 669-678).

Jakościowe badania nad odpornością psychiczną pielęgniarek pracujących na Oddziałach Intensywnej Terapii, które są narażone na wystąpienie problemów psychologicznych i stresu pourazowego, podjęli naukowcy ze Stanów Zjednoczonych, Meredith Mealerl, Jacqueline Jones i Marc Moss. Celem badawczym była identyfikacja mechanizmów odpornościowych stosowanych przez pielęgniarki na Oddziałach Intensywnej Terapii, które mają za zadanie zapobieganie PTSD i opracowanie skuteczniej terapii. Badanie przeprowadzono za pomocą wywiadów telefonicznych. Przebadano 27 pielęgniarek przy użyciu Skali Odporności, Connora-Davidsona, i zidentyfikowano różnice w czterech obszarach, takich jak światopogląd, kontakty społeczne, elastyczność poznawcza, samoopieka i własna równowaga. Badania przeprowadzono na grupie pielęgniarek odpornych na stres 
oraz na grupie pielęgniarek, u których przejawia się stres pourazowy, czyli PTSD. Pielęgniarki, które lepiej radzą sobie ze stresem, upatrywały to w czynnikach takich jak: praktyki duchowe, wsparcie społeczne, pozytywne relacje z innymi i optymistyczne podejście do życia. Natomiast pielęgniarki, które były mniej odporne na stres, wykazywały się niedoborem w sferze umiejętności nawiązywania i budowania pozytywnych relacji społecznych, nie miały w przeszłości wzorów do naśladowania, były podatne na wywoływanie w sobie destrukcyjnych myśli, w postaci żalu i braku optymizmu. Wniosek z przeprowadzonych badań mówi o tym, że pielęgniarki, które są odporne i radzą sobie lepiej z presją i stresem, stosują własne wyuczone umiejętności i odznaczają się nabytymi w trakcie życia cechami psychologicznymi. Naukowcy doszli do wniosku, że cechy charakteru i zdolności społeczne pozwalają na lepsze radzenie sobie z czynnikami wyzwalającymi stany napięcia i wchodzenie w stresujące sytuacje (Meredith i Jacqueline, 2012, s. 9).

\section{PODSUMOWANIE I WNIOSKI BADAWCZE}

Profilaktyka ukierunkowana na wzmacnianie odporności psychicznej jest sztuką samodoskonalenia ciała, psychiki i ducha, a wiedza badanych z zakresu profilaktyki społecznej, oparta na elementach paintballu i sztuki przetrwania, uruchamia w nich wyuczone zdolności, które zdecydowanie wpływają na ich sposób reagowania na trudności, zarówno w życiu zawodowym, rodzinnym, jak i szeroko pojętym społecznym. Badania nad wzmacnianiem odporności psychicznej dowiodły, że badani potraktowali intensyfikację jako pokonywanie trudności, przezwyciężanie własnych słabości i pracę nad sobą. Uczestnicy badań zdają sobie sprawę z tego, że poprzez połączenie oddziaływań profilaktycznych z elementami paintballu biorący w nich udział uczestnicy działań profilaktycznych są bardziej uważni na codzienne zagrożenia, rozwijają swoją wiedzę, wzmacniają odporność psychiczną i są bardziej uważni na różnego rodzaju zagrożenia. Regularna gra w paintball wzmacnia wiarę we własne możliwości, wspiera w uczeniu się wytrwałości i czyni człowieka silniejszym oraz bardziej uważnym na siebie. Na podstawie przeprowadzonych wywiadów i obserwacji można dojść do wniosków, że sztuka przetrwania i paintball ukazuje czynniki, które sprzyjają wzmacnianiu odporności psychicznej, a ludzie grający w paintball bardziej je dostrzegają i wykazują się silniejszymi bodźcami do wiary we własne zdolności. Badania dowiodły, że profilaktyka wzmacniania odporności, poprzez sztukę przetrwania i paintball u badanych, czyni ich otwartym na nowe wyzwania i wspiera w dążeniu do stawianych sobie celów życiowych. Zatem profilaktyka społeczna rozwija 
teorię na temat odporności psychicznej, która umożliwia człowiekowi praktykowanie jej, z korzyścią dla siebie i innych ludzi. Teoria ugruntowana to teoria procesu, a swoją własną pracę znamy lepiej, jako pracę w toku, która wskazuje na jej odkrywanie. Zadaniami teorii ugruntowanej jest umożliwienie wyjaśnienia zachowań, użyteczność dla teoretycznego rozwoju, przewidywanie i wyjaśnianie powinny wyposażyć praktyka w zrozumienie, jest strategią postępowania z danymi, dostarczającą sposobów konceptualizacji przy opisywaniu i wyjaśnianiu (Glaser i Strauss, 2009, s. 34).

Uczestnicy tego badania zauważyli, że bardziej przyjrzeli się sobie i poznali na sobie, jakie czynniki psychologiczne i społeczne powodują u nich wzmocnienie odporności psychicznej. Wyniki badań wskazały na to, że realizatorzy programów profilaktycznych mogą dokładniej i uważniej przyjrzeć się własnym cechom charakteru i poznać wnikliwiej własne słabości, ograniczenia i zasoby. Uczestnicy badań bliżej przyjrzeli się negatywnym skutkom społecznym i psychologicznym oraz różnym obciążeniom, które napotykają w codziennym życiu i w znaczący sposób wpływają na ich kondycję psychiczną. Ma to na celu, aby uczestnicy badań realizowali dopracowane przez siebie programy profilaktyczne, nad którymi pracują, doświadczając na sobie sposobów działania i technik wspierających i wzmacniających odporność psychiczną. Oznacza to, że możliwość poradzenia sobie w trudnych sytuacjach dostrzega się przez poznawanie własnej bezsilności oraz rozpoznawanie w sobie zaburzonych schematów myślowych i zachowań, co jest bardzo znaczącym czynnikiem wpływającym na uodparnianie człowieka. Elementy paintballu i sztuki przetrwania, wykonywane regularnie, mają wpływ na lepszą kontrolę wykonawczą człowieka i wzmacniają czynności sprzyjające zdrowiu. Badania nad Intensyfikacjq odporności psychicznej u ludzi grających w paintball, którzy sq realizatorami działań profilaktycznych były dla nich pewnego rodzaju superwizją, ponieważ badanie było konsultacją, weryfikacją własnych metod i sposobów pracy, a wyjaśnianie i odtwarzanie wywiadów oraz obserwacji za pomocą teorii ugruntowanej były dla badanych przyjrzeniem się samemu sobie. Superwizja stwarza terapeucie przestrzeń do refleksji. Dzięki temu może on, we wspierającej atmosferze, przyglądać się swojej pracy i własnym reakcjom, zastanawiać się nad nimi i szukać dróg, jakimi podąży wspólnie z pacjentem. Natomiast gdy superwizowany poczuje, że utknął w miejscu, może poddać dialog terapeutyczny w analizie odsłaniającej trudne punkty interakcji (Kenneth i Maria, 2004, s. 128). 


\section{Bibliografia}

Baltasar, G., (2010). Sztuka doczesnej mądrości. Gliwice: Wyd. Helion.

Fletcher, D., Sarkar, M. (2012). A grounded theory of psychological resilience in Olympic champions. Psychology of Sport and Exercise, 13 (5), s. 669-678.

Gaś Z., (2004). Szkolny program profilaktyki, istota, konstruowanie i ewaluacja. Poradnik metodyczny. Lublin: Wydawcza Fundacja Masz Szansę.

Glaser B. G., Strauss A. L. (2009). Odkrywanie teorii ugruntowanej. Kraków: Wydawnictwo Nomos.

Granosik, M. (2006). Profesjonalny wymiar pracy socjalnej. Katowice: Wyd. Naukowe ŚLĄSK.

Jastrow, J. (2007). The Psychology of Conviction. Whitefish.

Kenneth, E., Maria, G. C. (2004). Superwizja w psychoterapii. Gdańsk: Wyd. GWP.

Meredith, M., Jacqueline, J., Moss, M. (2012). Intensive Care Medicine. A qualitative study of immunity and post-traumatic stress disorder in ICU nurses in the United States, National Library of Medicine, 38, s. 9.

Urbaniak-Zając, D., Kos, E. (2019). Badania jakościowe w pedagogice. Warszawa: Wydawnictwo Naukowe PWN. 